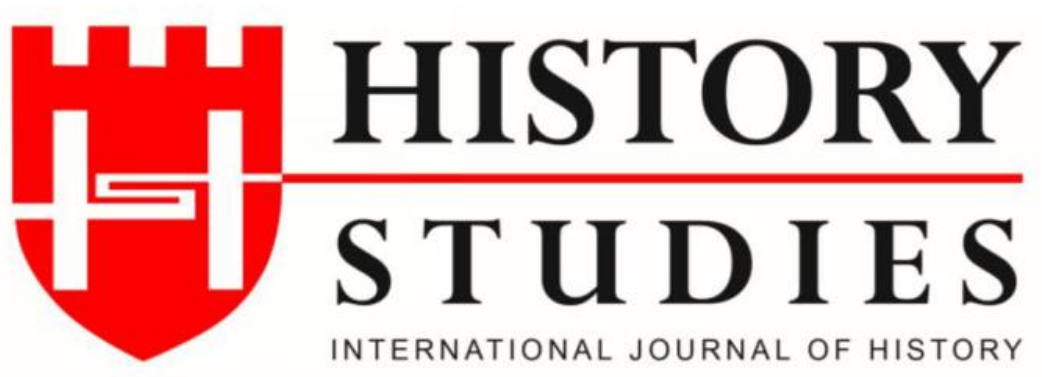

ISSN: 13094173 (Online) 1309 - 4688 (Print)

Volume 12 Issue 3, June 2020

DOI Number: 10.9737/hist.2020.868

Araştırma Makalesi

Makalenin Geliş Tarihi: 11.04.2020 Kabul Tarihi: 05.06.2020

Atıf Künyesi: Mehmet Aydın, "Mütareke Ortamında Yolsuzluk Tartışmaları: Siyah Pençe Olayı", History Studies, 12/3, Haziran 2020, s. 1085-1093.

\title{
Mütareke Ortamında Yolsuzluk Tartışmaları: Siyah Pençe Olayı*
}

\author{
Corruption Discussions in The Combat Environment: \\ Black Pence Incident
}

Dr. Mehmet Aydın

ORCID No: 0000-0002-4552-1913

Ondokuz Mayıs Üniversitesi

Volume 12

Issue 3

June

2020

Öz: Bu çalışma, Birinci Dünya Savaşının neden olduğu olağan üstü koşullarda, ortaya çıkan ve basına yansıyan yolsuzluk ve ihtikâr olaylarını ele almaktadır. Bu bağlamda özel olarak Siyah Pençe şirketi ekseninde gerçekleşen yolsuzluk ve ihtikâr olayları, Tasvir-i Efkar ve İkdâm gazetelerinde yer alan iddialar ışığında ortaya konulmuş; yapılan yolsuzluğun İttihat ve Terakki ile olan bağı ve halk üzerindeki etkileri incelenmiştir.

Anahtar kelimeler: İttihat ve Terakki, Basın, Siyah Pençe Şirketi, yolsuzluk, ihtikar.

Abstract:This paper deals with the corruption and profiteering incidents and their reflections to the press which emerged in the extraordinary circumstances caused by the World War, I. In this context, the corruption and profiteering incidents that especially took place in the axis of the "Black Paw Company" were put forward in the light of the allegations in "Tasvir-i Efkar" and "İkdâm" newspapers. The relationship between corruption and the Committee of Union and Progress and its effects on the society had been examined. Keywords: The Committee of Union and Progress, Press, Black Claw Company, corruption, profiteering

\section{Giriş}

Mütareke ortamında, İstanbul basınında Birinci Dünya Savası yıllarında yer alan yolsuzluk iddialarının temelini, İttihat ve Terakki yönetiminin uyguladığı ekonomik ve sosyal politikalar oluşturmaktadır. Savaşla birlikte ortaya çıkan olağan üstü koşullar, halkın ve ordunun temel ihtiyaç maddelerinin karşılanması hususunda, İttihat ve Terakki yönetimini zor durumda bıraktı. Genç nüfusun askere alınması, üretimin düşmesine neden oldu; ayrıca savaş esnasında Osmanlı devletinin denizden abluka altına alınması, ihtiyaç duyulan maddelerin dışarıdan

\footnotetext{
* Bu makale 1-2 Aralık 2018'de Samsun'da düzenlenen 12. Balkan Tarih Kongresinde sunulan bildirinin gözden geçirilmiş halidir.
} 
teminini zorlaştırdı. Ulaşımı sağlayan araç ve gereçlerin yetersizliği, ülke içerisinde kısmi de olsa üretilen malların, ihtiyaç duyulan yerlere sevkiyatını da güçleştirdi.

İttihat ve Terakki yönetiminin, bu zor koşullar karşısında izlediği politikaların çok da başarılı olduğunu söylemek mümkün değildir. Nitekim bu dönemde izlenen politikaların en önemli sonuçlarından birisinin, basına da yansıdığı gibi, yolsuzluklar şeklinde kendisini göstermesidir. Bu yolsuzluklar savaşın getirdiği nesnel koşullara bağlı olarak ortaya çıkmakla beraber, İttihat ve Terakki yönetiminin takip ettiği ekonomik politikalardan da kaynaklanmaktaydı. Birinci Dünya Savaşı yıllarında, İttihat ve Terakki yönetiminin basına uyguladığı sansür, gazete sayısında önemli bir düşüşe neden oldu. Bu dönemde, sansür politikaları yüzünden hükümetin uygun gördüklerini yazmak basın için zorunlu hale geldi. Yönetime karşı herhangi bir eleştiride bulunmak mümkün değildi. Birinci Dünya Savaşı'nın sonuna doğru, yolsuzluk olaylarında görülen artış nedeniyle, İttihat ve Terakki yönetimi bu tür haberlerin basında yer almasına kısmen izin vererek, sansürü hafifletmek zorunda kaldı. Bunun nedeni, iktidarın başarısızlığının halkta yarattığı olumsuz etkileri nispeten bastırmak ve halkı psikolojik açıdan rahatlatmaktı. Ancak bütün yolsuzlukları, özellikle de orduya yönelik olanları yazabilmek, yine de mümkün değildi. Bu tür yolsuzlukları haber yapabilmek, ancak mütareke yıllarında mümkün olabildi. İttihat ve Terakki'nin yolsuzluklarına ilişkin olayları haber yapmak gazetecilerin başlıca uğraşları haline geldi. ${ }^{1}$

Savaş yıllarında ekonomi yönetimi ve denetimini, İttihat ve Terakki iktidarı ele aldı. Kara Kemal ile İdare Heyeti Genel Sekreteri İsmail Hakkı'ya İstanbul'daki ekonomik süreçleri denetleme görevi verildi. Bu yetki, İstanbul dişında ise, partinin ileri gelenlerine tevdi edildi. Denetimin, parti ileri gelenleri tarafindan sağlanmadığı durumlarda, ekonomik ve sosyal hayatın bazı alanlarını düzenlemek amacıyla kurulan komiteler tarafından yürütüldü. ${ }^{2}$ Ekonomi yönteminin İttihat ve Terakki'nin eline geçmesi, partinin kendi yandaşlarını zengin etmesinin yolunu açtı. Bu hususla ilgili olarak Ali Kemal Sabah Gazetesinde yayınladığ "İaşe Nezareti" başlıklı yazısı oldukça ilgi çekicidir. O, İttihat ve Terakkinin güç ve kudretini canlandırmak ve devam ettirmek için ekonomik olarak yaptığı etkinlikleri şu şekilde değerlendirmektedir:

“... devr-i fesahatin bir maksudu vardı, o da ferdayı (yarın) hiç nazarı itibara almayarak günü gününe yaşamaktı. Devleti, milleti batırarak bir hizbi, bir zümre-i eşhası yaşatmak, zenginlenmek idi. Çetelere yakışan böyle bir gaye, kendini bilir bir hükümetin menfurudur."3

İttihat ve Terakki'nin savaşla birlikte ülke ekonomisiyle ilgilenmesi ekonomide devletçi anlayışın ortaya çıkışına neden oldu. ${ }^{4} \mathrm{Bu}$ dönemde devletin ekonomik faaliyetlere müdahale etmesi, korumacı bir dış ticaret politikasının izlenmesine, dış ticaretin de fiilen devletin eline geçmesine sebep oldu. Dış ticarete paralel olarak "devlet iktisadiyatının" içe dönük faaliyetleri de İttihat ve Terakki tarafindan yürütülmeye başlandı. Kemal beyin öncülügünde oluşturulan Heyet-i Mahsus-i Ticariye özellik İstanbul'un iaşesi başta olmak üzere, pek çok ekonomik faaliyeti devlet adına üstlendi. ${ }^{5}$ Ancak devletin ekonomiye müdahalesi, ortaya çıkan sorunları çözmekten çok devlet eliyle yolsuzluk kapılarının aralanması sonucunu doğurdu. Birçok devlet

\footnotetext{
${ }^{1}$ Orhan Koloğlu, 1918 Aydınlarımızın Bunalım Yılı Zaferi Nihai'den Tam Teslimiyete, Boyut Yay., İst. 2000, s. 2635; Mehmet Aydın, "İttihat ve Terakki'ye Yönelek İstanbul Basınında Yer Alan Bazı Yolsuzluk İddiaları", Turkish Studies International Periodical For the Languages, Literature and History of Turkish or Turkic, Volume 3/7 Fall 2008, s. 696-697.

${ }^{2}$ A. L. Macfie, Osmanlının Son Yılları 1908-1923, çev.: Damla Acar-Funda Soysal, Kitap Yay., İst. 2003, s. 136

${ }^{3}$ Sabah, 3 Kanun-i Sani 1335/3 Ocak 1919. No: 1046

${ }^{4}$ Zafer Toprak, Ittihad-Terakki ve Cihan Harbi Savaş Ekonomisi ve Türkiye'de Devletçilik 1914-1918, Homer Yay., İst 2003, s. 13-14

${ }^{5}$ Zafer Toprak, Türkiye’de Ekonomi ve Toplum Milli İktisat-Milli Burjuvazi, Yurt Yay., İst. 1995, s. 6
} 
görevlisinin adı yolsuzluk olaylarına karıştı. ${ }^{6}$ Nitekim Maliye Nazırı Abdurrahman Bey, 5 Ocak 1919 'da Sabah gazetesine verdiği beyanatta bu hususu gündeme getirerek şöyle demiştir:

"Bilirsiniz ki, bu memlekette bütün muamelat-1 ticariye ve vesait-i nakliyeyi, hükümet yed-i inhisarına almıştı. Memurlar, mebuslar alışverişe koyulmuş, resmi daireler ticarete girişmiş, heyeti umumiyesi adeta bir kazanç makinesi haline getirilmişti. Bu günkü sefalet ve felaketlerin asıl menbaını teşkil eden bir takım cemiyetler, şirketler, müesseseler gibi ticaret perdesi arkasında her türlü teşebbüs haricinde kazançlar vücuda getirmek, onunla ahali ve orduyu geçindirdikten sonra, milyonlarca liralar elde etmek için bir İaşe Nezareti teşkil edilmişti. Hazineden 5 milyon lira sermaye ve bunun haricinde maaş ve masraf için bütçeden de, 2 milyon lira tahsisat verilerek bir daire-i resmiyeye inkilâb ettirilmişti. İşe baslar başlamaz, sermayenin 4 milyon lirası bir defada hazineden alındı. Bunun 3,5 milyon lirası derhal yağma edildi. Parayı alan gitti. Haber yok, hesap yok, iaşe için de bir şey geldiği yok idi.",

Maliye Nazır'ı Abdurrahman beyin beyanatını, Alemdar Gazetesinde yer alan şu haber de teyit eder niteliktedir. Haberde, tahsisat-1 mestureden (örtülü ödenek) usulsüz olarak bazı gazeteci, tüccar, mebus ve mutasarrıflara paralar verildiği iddia edildi. Ordunun levazım işleri de, geniş yetkilerle İsmail Hakkı Paşa'ya verildi. Bu kişinin adı yolsuzluklara karışmıştı. Buna rağmen Enver Pasa ordunun iaşesinin onsuz temin edilemeyeceği düşüncesini ileri sürerek, görevinde kalmasını sağladı. İsmail Hakkı Paşa'nın görevden alınması hususunda 1srar edilirse kendisinin istifa edeceği tehdidinde bulundu. ${ }^{8}$

Osmanlı İmparatorluğunda Türkler daha ziyade çiftçi, asker veya işçi olurlardı. Zengin olmayı sağlayan işler azınlıkların elindeydi. Bu durum, ülkenin ekonomik hayatının azınlıkların eline geçmesine sebep olmuştu. Ancak azınlıkların büyük bir kısmı, bu zenginliklerini son dönemde Osmanlı devletini parçalamaya yönelik kullanmaya başladı. ${ }^{9}$ Bundan dolayı İttihat ve Terakki, ülkenin kurtuluş ve refahını sağlayabilmek için Müslüman-Türk iş adamları ve zenginler oluşturmak amacıyla "milli iktisat" ve "iktisadi uyanış" politikasına yöneldi. İttihat ve Terakki'nin 1916 kongresi milli iktisat politikası ve esaslarının belirlenmesi bakımından önemli bir gelişme oldu. ${ }^{10}$ Birinci Dünya savası, bu politikanın hayata geçirilmesi için firsat olarak görüldü. Rum iş adamları, çeşitli şekillerde yıldırıldı. Ermeni tehciri ile meydana gelen boşluklar, Müslüman-Türk girişimciler tarafından doldurulmaya çalışıldı. Bunların başarılı olabilmesi için de ihtikârla mücadele faaliyetleri özellikle gayri müslimlere yöneltildi. Böylece Müslüman-Türk tüccarlarının rakiplerinin tasfiyesinin yolu açıldı. Savaşa rağmen, bu dönemde, 123 tane anonim şirket kuruldu. Ancak, bu defa da, Müslüman-Türk kesime ayrımcılik yapılarak sermayelerinin arttırılmasına yönelik spekülatif kazanç sağlamalarına göz yumuldu. Milli iktisat politikasına uygun olarak bu dönemde kurulan şirketlerin ismi, milli kelimesiyle başlıyordu. ${ }^{11}$ İttihat ve Terakki hükümetinin maliye nazırı Cavit Bey'in 3 Mart 1917'de yaptığı bütçe konuşmasında meşru olmayan yollardan elde edilmiş olsa bile, milli sermeyenin ticaret sahasında sermeyenin ticaret sahasında nemalandırılmış olmasını memnuniyetle karşıladığını belirtmesi, bu politikanın uygulandığının resmi ağızlardan ifade edilmesi bakımından önemlidir. ${ }^{12}$ İttihat ve Terakki'nin bunun için yeterli önlem alamaması, hatta zaman zaman bu tür spekülatif ortamların oluşmasına kimi gerekçelerle katkı sağlaması, bu işlerle uğraşanları

\footnotetext{
${ }^{6}$ Mehmet Aydın, Ittihat ve Terakki'ye Yönelek İstanbul Basınında Yer Alan Bazı Yolsuzluk İddiaları, s. 697-698.

${ }^{7}$ Sabah, 5 Kanun-u Sani 1335/5 Ocak 1919, No: 10466.

${ }^{8}$ Bünyamin Kocaoğlu, Mütarekede İttihatçılık (İttihat ve Terakki Fırkası'nın

Dağılmas1), Temel Yay., İst. 2006, s. 244.

${ }^{9}$ Yusuf Hikmet Bayur, Türk Inkılâbı Tarihi, cilt: III, kısın: 4, Türk Tarih Kurumu

Yay., Ank. 1983, s. 518.

${ }^{10}$ Zafer Toprak, Türkiye'de Ekonomi ve Toplum (1908-1950) İttihat Terakki ve Devletçilik, Yurt Yay., İst. 1995, s. 2.

${ }^{11}$ Zafer Toprak, Milli İktisat, s. 6-7

${ }^{12}$ Vedat Eldem, Harp ve Mütareke Yıllarında Osmanlı Imparatorluğu'nun Ekonomisi, Türk Tarih Kumru Yay., Ank. 1994, s. 131-132.
} 
cesaretlendiriyordu. ${ }^{13}$ Diğer taraftan karaborsa, istifçilik, vurgun, kamu fonlarını zimmete geçirme gibi yöntemler kullanmak suretiyle yeni bir zengin sınıfı türedi. Bu sınıf daha ziyade küçük tüccarlar, bürokratlar veya İttihat ve Terakkiye yakın kişilerden oluşuyordu. Aslında bunların zenginliği köklü bir ekonomik geleneğe ve geçmişe dayanmıyordu, sadece iktidarın kayırmasıyla palazlanma seklinde ortaya çıkıyordu. Bu yeni zenginler sınıfı, geçmişte nispeten varolan eşitlikçi toplum yapısını ortadan kaldırdı ve zengin ve fakir sınıfının belirginleştiği yeni bir toplum yapısının ortaya çıkardı. ${ }^{14}$

\section{Siyah Pençe Şirketi ve Yolsuzluklar:}

İttihat ve Terakki iktidarı döneminde kurulan ve Mütareke dönemi basınında adı ihtikarla anılan en önemli şirketlerden birisi Siyah Pençe idi. Bu şirketin, Birinci Dünya Savaşı'nda ticari faaliyetlerde bulunduğu; harbiye levazımatı için tahsis olunan vagonlardan önemli ölçüde istifade temin ederek Almanya ve Avusturya'dan külliyetli miktarda ithalat ve de Osmanl1 ülkesinden de kapsamlı ihracat yapmak suretiyle ciddi kazançlar elde ettiği iddia edilmiştir. Harbiye Nezareti levazımatı için tahsis edilen vagonların arasına bu şirkete ait ve "x y z" alamet-i farikasıyla vagonlar eklenmek suretiyle getirdikleri malları çok fahiş fiyatlarla piyasaya sürüp, haksız kazanç elde ettikleri yönünde iddialar ortaya atılmıştır. ${ }^{15}$ Şirketin varlığ Fransız zabıtası tarafından tespit edilmiş; Fransız zabıtası şirketin ticari muamelelerine vakıf olmuş ve tahkikat yapılmasını gerekli görmüştür. O tarihte de faaliyetlerini sürdürmekte olan Siyah Pençe şirketinin elinde külliyatlı miktarda para bulunması hasebiyle siyasi meselelerde rol ifa etmesi ihtimali düşünülerek, mesele Divan-1 Harb-i Örfi'ye havale edilmiştir. ${ }^{16}$ Siyah Pençe şirketinin ticari faaliyetlerinde dönemin hükûmeti İttihat ve Terakki'nin önemli şahsiyetlerinden yardım aldığı ileri sürülmüş, özellikle Topal İsmail Hakkı Paşa sayesinde cihet-i askeriye namına hastaneler, iaşe, men-i ihtikâr ve sair mahallerin ihtiyaçlarını karşılamak için Almanya ve Avusturya'dan getirilen şeker, kibrit, eczayı tıbbiye sair maddeler bu şirkete mensup şahsiyetlerin fahiş kazançlar elde etmesine sebep olmuştur. Şirket, aynı zamanda hem Almanya hükûmeti hem de Osmanlı hükûmetiyle mukavele akdederek, eşya mübadelesinden ve aynı eşyayı piyasaya sürmekten istifade etmiştir. Şirket, AlmanyaAvusturya vagonlarıyla, İsviçre'den transit suretiyle geçirilen vagonları \% 80 nispetinde tekeline almış, diğer taraftan da İzmir, Bandırma, Halep Haydarpaşa hatlarında da nüfuz elde etmişti. $^{17}$ İttihatçı eski Rumeli hat komiseri Kaymakamı Şakir Nimet Bey askeri mühimmat taşıyan marşandizlerin arasına Siyah Pençe şirketine ait vagonları takarak, aynı zamanda transit işlemlerine de müdahale ederek, bu vagonlardaki emtianın ülkeye girişini sağlamaktaydı. Bu şahsın Sirkeci'ye gelen şeker vagonlarını gümrük idaresinden kaçırttı̆̆ 1 ve şirketin altın ve deri kaçakçıllı̆̆ işinde de yardımcı olduğu ileri sürülmüştür. ${ }^{18}$ Buna ek olarak, İttihad ve Terakki cemiyeti Merkez-i Umumisinin de Siyah Pençe Şirketine yardım ettiği iddiaları ileri sürülmüştür. Cemiyetin bazı kulüplerine, şirkete kolaylık sağlanması konusunda talimatlar gönderdiği; Siyah Pençe şirketinin hemen hemen İttihad ve Terakki Cemiyeti'nin güç elde etmesiyle birlikte teşkil edilmiş olmasının, İttihad ve Terakki Cemiyeti'nin bu şirketi kendi emellerini gerçekleştirmek maksadıyla kurdurduğu fikrini uyandırdığı tezleri ortaya atılmıştır.

\footnotetext{
${ }^{13}$ Vakit, 19 Ağustos 1334/1918, No: 299.

${ }^{14}$ François Georgeon, “Gülüsün ve Gözyaslarının Kıyısında”, İstanbul 1914-1923, haz.: Stefanos Yerasimos, çev: Cüneyt Akalın, İletisim Yay., İst. 1997, s. 81-84.

${ }^{15}$ Tasvir-i Efkâr, 18 Ağustos 1335/1919; No: 2816.

${ }^{16}$ Tasvir-i Efkâr, 18 Ağustos 1335/1919; No: 2816.

${ }^{17}$ Tasvir-i Efkâr, 27 Ağustos 1335/1919; No: 2825.

${ }^{18}$ Tasvir-i Efkâr, 27 Ağustos 1335/1919; No: 2825.
}$$
\text { (2020 }
$$ 
Hatta şirketin bazı yerlere yardımlarda bulunduğu, Kara Kemal Bey'in ailesine 24 bin lira verdiği haberleri yayılmıştır. ${ }^{19}$

Siyah Pençe Şirketi'nin, İttihat ve terakki'ye ek olarak, dış bağlantılarının da bulunduğu; Alman ve Avusturya fabrika ve ticari müesseseleriyle ilişkiye girdiği; bu ilişkiyi doğrudan doğruya İstanbul'daki vekilleri aracılığıyla yürüttüğü iddia edilmiştir. ${ }^{20} \mathrm{Bu}$ şirkete, Musevi ve Rum tüccarlardan birçoğunun dahil olduğu elde edilen evrak ve defterlerden tespit edilmiş, bu kişilerin de eski Şark şimendiferleri hat komiseri kaymakamı Şakir Nimet beyden fevkalade yardım gördükleri söylenmiştir. Şirketi teşkil eden tüccarların ise \%75'ni Musevi, \%25'inin de Rum ve Ermeni olduğu ileri sürülmüştür. ${ }^{21}$

Şirketin, askeri limanlar idaresinde de önemli faaliyetler gerçekleştirdiği anlaşılmaktadır. Buradaki müdürler, muavinler, kâtipler en ketum kişilerden seçilmiş, yapılan işlemlerde özel şifreler kullanılmış, memurlar birçok usulsüzlüklere kayıtsız kalmışlardır. Eski Bahriye Nazırı Cemal Paşa Suriye'de bulunduğu esnada limanlar idaresine ipek temin etmekle fazlaca meşgul olmuş, mahalli tüccarların ipek ihracını men ederek en az bir milyon liralık ipeği bir defada toplamıştır. İhracat yasaklandığı için bu ipekler balya balya müsadere edilerek Haydarpaşa'ya, oradan da limanlar idaresi deposuna gönderilmiştir. Buradan da Siyah Pençe şirketine mensup tüccarların eline geçmiştir. Hatta Cemal Paşa, İsmail Hakkı Paşa'ya çektiği şifrelerle pazarlık dahi yapmaya cüret etmiştir. Limanlar idaresindeki en dikkat çeken işlemlerden birisi, 29. 10. 1334/1918 tarihinde tahrif edilen 300 balyalık ipek işlemidir. Malum tüccarlardan birine askeri limanlar idaresi ambarından 400 bin liralık ipek devredilmiştir. Yine aynı günde yazılan tezkireye 1.3.1334/1918 tarihi vaz edilmiştir. Evrak-i müteselsile No'su takip edilemeyerek evrak defterine tahrif edilmiş tarihe ait yani yedi ay evvelki No'lar arasına bir numara ilave edilmek suretiyle şirkete oldukça büyük menfaat temin edilmiştir. ${ }^{22}$ Askeri limanlar idaresi ambarlarında bulunan kibritler de eski Maarif Nazırı Şükrü Bey ve arkadaşlarına her defasında 1500-2000 sandık kibrit verilmiş ve her defasında adı geçen şirketin mensuplarına en az 10 bin lira kazanç temin edilmiştir. Mütareke'nin imzasından bir buçuk ay önce Askeri Limanlar İdaresi kasasından Yüzbaşı Arif Bey'e 400 bin lira verilerek elindeki hususi şifreyle Gence'ye pamuk, tiftik, yağ satın alması için gönderilmiştir. 29 Ekim'de Refik Bey, Arif Bey'e telgraf çekerek kalan parayla geri dönmesi, şayet para kalmamışsa satın alınan eşyayı Almanlara teslim etmesi, defterleri de emin bir yolla göndermesi gerektiği bildirmiştir. Yalnız Arif Bey'den ses çıkmamıştır. Siyah Pençe şirketi hesabına verildiği tahmin edilen 400 bin lira da bu suretle usulsüz bir biçimde başkalarının eline geçmiştir. ${ }^{23}$

Şeker ve gaz gibi zaruri ihtiyaç maddeleriyle, manifatura eşyalarını ülkedeki satış fiyatından daha ucuza getirdikleri halde, Siyah Pençe şirketi aracıllğıyla yüksek fiyatlarla halka satıliyordu. İttihat ve Terakkiye mensup önde gelen kişiler, bu faaliyetleri kendi yandaşlarına hasretmişlerdi. Daha ucuz fiyatla ülkeye ithalat yapıp piyasaya mal sürmek isteyen tüccarların bu faaliyetlerine de engel olmuşlardır. Dolayısıyla, ithalat faaliyetlerini, Siyah Pençe şirketinin tekeline vererek, ihtikâra neden olmuşlardır. Oluşturulan bu tekelle, ticaret yapan insanların karının yüzde doksan dokuzu İttihat ve Terakki yandaşlara bırakmak zorunda bırakılmıştır. Bu

${ }^{19}$ Tasvir-i Efkâr, 18 Ağustos 1335/1919; No: 2816.

${ }^{20}$ Tasvir- Efkâr,27 Ağustos 1335/1919; No: 2825.

${ }^{21}$ Tasvir-i Efkâr, 18 Ağustos 1335/1919; No: 2816.

${ }^{22}$ Tasvir-i Efkâr, 27 Ağustos 1919; No: 2825.

${ }^{23}$ Tasvir-i Efkâr, 27 Ağustos 1335/1919; No: 2825. 
konuda hiçbir ahlaki değer tanımadıkları; zorbalıkla hükümetin yetkilerini kullandıkları, baskı kurarak kendi mevkilerini korumaya çalıştıkları, hatta bazen baskıyı da yeterli görmeyerek halkı ezmek suretiyle iktidarlarını bir süre daha sürdürmek gayesi güttükleri anlaşılmaktadır. Güçlü bir iktisadi teşkilatın olmaması nedeniyle bu türden yolsuzluklar uzun süren savaş y1llarında, İttihat ve Terakki hükümetinin de desteğiyle kolayca yapılabilmiştir. ${ }^{24}$

Siyah Pençe şirketinin faillerinin yaptıkları bu ihtikâr faaliyetlerinin kanuni soruşturmaya tabi tutulduğu görülmektedir. Bu bağlamda, Siyah Pençe şirketine katılarak ihtikâr yaptıkları iddia edilen, eski Ticaret ve Ziraat Nazırı Ahmet Nesimi ve Mustafa Şeref beylerle Ticaret ve Sanayi Odası Reis Muavini Mustafa; eski Âmedi Divan-1 Hümayunu Suphi ve Eski Ticaret Müdür Umumisi Hüseyin Münir, tüccardan Haydar beyler Divan-1 Harbi Örfiye çağrılacağ1 ifade edilmiştir. Bunların dışında, bu mesele hakkında maliye müfettişlerinden Selahattin Beyin de ifadesine başvurulacağ 1 belirtilmiştir. ${ }^{25}$ Divan-1 Harbi Örfi Müdde-i Umumisinin iddianamesinde, bu ihtikâr ve yolsuzluk işine karışanların üzerine cesaret ve kararlılıkla gidileceği ve uzun süredir mağdur olan halkın vicdanı rahatlatacak yasal işlemlerin yapılması konusunda hassas davranılacağı ifade edilmiştir. Nafia Nezaretindeki resmi evraklarında, ihracat ve ithalat işleri, İttihat ve Terakki nazırlarının gözetiminde teşekkül ettirilen komisyonlar tarafından kontrole tabii iken, Siyah Pençe şirketinin tespit edilen faaliyetleri ihtikârın önlenmesi yerine, bilakis teşvik edildiği ve bunlara her türlü yardım ve kolaylığın gösterildiği iddia edilmiştir. Yine Hariciye Nezareti celilesine Fransız hükümetinin Fevkalade Komiserliğinden gelen 2 nolu notaya ekli Şark Şimendiferleri Askeri İdaresi tarafından gönderilmiş evrakların tercümesinde de, ithalat ve ihracat komisyonu İttihatçılara ihracat ruhsatnameleri vermekte ve bunlar da kıymet üzerinden yüzde 7 nispetinde bir vergi ödedikten sonra aynı ruhsatnameyi \% 110 ile \% 150 nispetinde tekrar başkalarına sattıkları ifade edilmektedir. Siyah Pençe şirketine, İttihat ve Terakki hükümeti emriyle, Şark Şimendiferleri üzerinden yetki sahibi olan Avusturya-Alman Mubayaa Komisyonu müracaat etmekteydi. Almanya-Avusturya Mubayaa komisyonu da bir vergi karşılığında Siyah Pençe grubunun x, y, z vagonlarını kullanmalarına izin veriyordu. İttihat ve Terakki hükümetinin askeri komiseri de Siyah Pençe grubundan menfaat elde etmek suretiyle emtia kalemine irsaliyeleri için emir vererek Avusturya-Almanya Mubayaa komisyonuna fahiş vergi ödemesi karşılığında Siyah Pençe şirketinin ithalat muamelesiyle meşgul oluyor; dolayısıyla İttihat ve Terakki hükümetinin himaye ettiği Siyah Pençe şirketinin birinci derecede gerekli olan maddeler için yüzde 2251 ve diğer maddeler için de yüzde 4000 'den fazla para ödeyen ahaliyi soymak suretiyle haksız kazanç elde etmesine göz yumuyordu. Bu olaya, İthalat ve İhracat komisyonu ile AvusturyaAlmanya Mubayaa Komisyonu ve Rumeli Şimendiferi Osmanlı Askeri komiseri Şakir Nimet beyin de dâhil olduğu anlaşılmaktadır. Yine bu işi yapanların sıradan insanlar olmayacağı, gayet iyi örgütlenmiş bir çete işi olduğu, Alman Devletinin İstanbul sefaretinde müteşekkil tercüman dairesinin yardımlarının da olduğu ileri sürülmüştür. Almanya, Osmanlının her türden idari tasarrufuna müdahale etmekteydi; dolayısıyla bu kapsamlı yolsuzluğu hayata geçirmede, onların rolünün de bulunması aşikârdır. Hatta ithal edilen malların, Sefarethanedeki özel memurlar ve Ermeni kökenli hamallar aracılığıyla mahzen ve depolara aktarıldığı ve oradan da

${ }^{24}$ İkdam, 14 Eylül 1335/1919; No: 8107.

${ }^{25}$ Ikdam, 14. Eylül 1335/1919; No: 8107. 
çeşitli vasıtalarla gerekli olan kişilerin evlerine ve talep eden muhitlere sev edildiği iddia edilmiştir. $^{26}$

İttihat ve Terakkinin milli iktisat politikası bağlamında Türk ve Müslüman girişimci sınıfın oluşturulması düşüncesinin, bu türden faaliyetlerin gerçekleştirilmesinde rol oynadığı; bu faaliyetler gerçekleştirilirken gayri müslim tüccarlarla da ilişki kurulduğu anlaşılmaktadır. Bu yolsuzluklar ve ihtikâr, temel ihtiyaç maddelerinin fiyatlarının yükselmesine sebep olmuş, arztalep dengesini bozmuş, yoksul insanların yaşam imkanlarını ortadan kaldırmıştır. Nitekim Sihhıye Müdüriyeti tarafından İstanbul'da açlıktan ölen insanların listesinin yapıldığı; Divan-1 Harbi Örfi Müdde-i Umumi muavinlerinden Ferudun Bey tarafindan Heyet-i Tahkikiye verilen Siyah Pençe talepnamesinde bu listeye yer verildiği; insanların ölmesinden Siyah Pence şirketinin sorumlu tutulduğu anlaşılmaktadır. Açlıktan ölen insanların bu listede şu şekilde yer almıştır: 1914 (1330)'da, 17,714; 1915 (1331)'de 17,980; 1916 (1332)'da 18,766; 1917 (1333)'da 24,733 ve 1918 (1334)'de 23, 642 kişinin açlıktan öldüğü belirtilmektedir. Bunların dışında şekersizlik ve gıdasızlık yüzünden vefat eden çocukların miktarının 6,649'da ulaştığı söylenmektedir. Ülkede yapılan yolsuzluklardan dolayı, giyecek bulamayıp da vücutlarını harici etkilerden koruyamayarak vefat eden ihtiyarların sayısının da 2,899 kişi olduğu anlaşılmaktadır. Ayrıca bu sayıya dâhil edilmeyen gizlide kalmış daha pek çok kişinin öldüğü bildirilmektedir. ${ }^{27} 19$ Eylül 1919 tarihli İkdam gazetesindeki haberde şöyle denilmektedir:

"Menafi-i hasiselerini temin ile keselerini doldurmak için ihtikar dolabını kurarak milletin kanını emen ve \% 500o'den fazla kar eden Siyah Pençe grubunun yaptığı fenalıklar ile ihtikarın derece-i fecaatini bu rakamlar kadar hiçbir şey göstermez." 28

Volume 12 Issue 3 June 2020

\section{Sonuç ve Değerlendirme}

Mütareke yıllarında, savaşla birlikte ortaya çıkan olağan üstü koşullar, halkın ve ordunun temel ihtiyaç maddelerinin karşılanmasını zorlaştırmış; yine genç nüfusun askere alınması, üretimin düşmesine neden olmuş; ayrıca savaş esnasında Osmanlı devletinin denizden abluka altına alınması, ihtiyaç duyulan maddelerin dışarıdan teminini güçleştirmiştir. Ekonomide ortaya çıkan güçlükleri aşmak için, iktidarda olan İttihat ve Terakki yönetimi, milli ve devletçi bir ekonomi politikasına yönelmiştir. Ancak politikaların yeter düzeyde hukuki temellerinin oluşturulamaması ve ortamın karmaşıklığı nedeniyle, pek çok yolsuzluk ve ihtikâr olayı patlak vermiştir.

Birinci Dünya Savaşı'nın sonuna doğru, yolsuzluk olaylarında görülen artış nedeniyle, İttihat ve Terakki yönetimi bu tür haberlerin basında yer almasına kısmen izin vererek, sansürü hafifletmek zorunda kalmıştır. Bunun temel nedeni, iktidarın başarısızlığının halkta yarattığı olumsuz etkileri nispeten kırmak ve halkı psikolojik açıdan rahatlatmak olduğu anlaşılmaktadır. Ancak bütün yolsuzlukların, özellikle de orduya yönelik olanları yazabilmek, yine de mümkün olmamış; bu tür yolsuzlukları haber yapabilmek, ancak mütareke yıllarında mümkün olabilmiştir. Basın özgürlügünün nispeten artışı ve Mütareke döneminde ortaya çıkan İttihat ve Terakki aleyhtarlığının etkisiyle birlikte, İttihat ve Terakki’nin yolsuzluklarına ilişkin olayları

${ }^{26}$ İkdam, 5 Eylül 1335/1919; No: 8108; 1 Eylül 1335/1919; No. 8109.

${ }^{27}$ İkdam, 19 Eylül 1335/1919; No: 8115.

${ }^{28}$ Ikdam, 19 Eylül 1335/1919; No: 8115. 
haber yapmak gazetecilerin başlıca uğraşları haline gelmiştir. Basına yansıyan bu yolsuzluk ve ihtikâr iddialarının en önemlisi, Siyah Pençe şirketi aracılığıyla yapılanıdır. Söz konusu şirketin, uluslararası bağlarının bulunduğu; İttihat ve Terakki iktidarıyla yakın ilişkiye girdiği; özellikle ithal edilen mallar üzerinde güçlü bir tekel oluşturduğu; bu tekel yüzünden, temel ihtiyaç maddelerinin fiyatının çok yükseldiği iddia edilmektedir. Şirkete, Avusturya-Almanya kökenli kişiler ile İttihat ve Terakki yönetiminin destek sağladığı, bu sayede İttihat ve Terakki Cemiyetine mensup pek çok kişinin haksız kazanç elde ettiği iddia edilmiştir.

Şirketin Mütareke döneminde de faaliyetlerini devam ettirmesi, güçlü bir sermayeye hükmetmesi ve İttihat ve Terakkiye yakın olması siyasi bir takım kaygıların ortaya çıkmasına neden olmuş; bu nedenle, İtilaf devletleri konuyla müdahil olmuştur. Bu bağlamda Fransa'nın İstanbul'daki Olağanüstü Komiserliği olayın ortaya çıkmasında ve adli soruşturmaya tabi tutulmasında rol oynamıştır. Buna bağlı olarak Divan-1 Harbi Örfi idaresince iddianame hazırlandığ 1 , konunun çok boyutlu olarak soruşturulduğu anlaşılmaktadır. Ancak soruşturmanın akıbetini öğrenmek maksadıyla basında yaptığımız araştırmada, konuyla ilgili bir bilgiye ulaşamadığımızı belirtmek gerekir. Muhtemelen Anadolu'da başlayan Milli Mücadele süreci, kazanılan zafer ve sonraki gelişmeler, İstanbul hükümetinin tasfiye olmasına yol açmış; bu sürecin akim kalmasına neden olmuştur.

Kaynakça:

AYDIN, Mehmet, "İttihat ve Terakki'ye Yönelik İstanbul Basınında Yer Alan Bazı Yolsuzluk İddiaları", Turkish Studies International Periodical For the Languages, Literature and History of Turkish or Turkic Volume 3/7 Fall 2008, s. 696-697.

BAYUR, Yusuf Hikmet, Türk Inkılâbı Tarihi, cilt: III, kısın: 4, Türk Tarih Kurumu, Yay., Ank. 1983.

ELDEM, Vedat, Harp ve Mütareke Yıllarında Osmanlı İmparatorluğu'nun Ekonomisi, Türk Tarih Kumru Yay., Ank. 1994.

GEORGEON, François, "Gülüsün ve Gözyaşlarının Kıyısında", İstanbul 1914-1923, haz.: Stefanos Yerasimos, çev: Cüneyt Akalın, İletisim Yay., İst. 1997.

İkdam, 1 Eylül 1335/1919; No. 8109.

İkdam, 14. Eylül 1335/1919; No: 8107

Ikdam, 19 Eylül 1335/1919; No: 8115.

İkdam, 5 Eylül 1335/1919; No: 8108.

KOCAOĞLU, Bünyamin, Mütarekede İttihatçılık (İttihat ve Terakki Fırkası'nın Dă̆ılması), Temel Yay., İst. 2006.

KOLOĞLU, Orhan, 1918 Aydınlarımızın Bunalım Yılı Zaferi Nihai'den Tam Teslimiyete, Boyut Yay., İst. 2000.

MACFIE, A. L. Osmanlının Son Yılları 1908-1923, çev.: Damla Acar-Funda Soysal, Kitap Yay., İst. 2003.

Sabah, 3 Kanun-i Sani 1335/3 Ocak 1919. No: 1046.

Sabah, 5 Kanun-u Sani 1335/5 Ocak 1919, No: 10466.

Tasvir- Efkâr, 27 Ağustos 1335/1919; No: 2825. 
Tasvir-i Efkâr, 18 Ağustos 1335/1919; No: 2816.

TOPRAK, Zafer, Ittihad-Terakki ve Cihan Harbi Savaş Ekonomisi ve Türkiye'de Devletçilik 1914-1918, Homer Yay., İst., 2003.

TOPRAK, Zafer, Türkiye'de Ekonomi ve Toplum (1908-1950) Itttihat Terakki ve Devletçilik, Yurt Yay., İst. 1995.

TOPRAK, Zafer, Türkiye'de Ekonomi ve Toplum Milli İktisat-Milli Burjuvazi, Yurt Yay., İst. 1995.

Vakit, 19 Ağustos 1334/1918, No: 299. 